\title{
Neonatal Death in Low Birth Weight Infants in Basrah Maternity \& Children Hospital at 2008
}

\author{
Dr. Basim Abdul Kareem Abdul Hassan ( M. B. Ch. B. F, F.I.C.M.S.) \\ Assistant professor Dr. Aida Abdul Kareem ( Department of Pediatrics / College of \\ Medicine / University of Basrah )
}

\begin{abstract}
Background :

Low birth weight( less than 2500 grams) that includes preterm birth and small for gestational age, is regarded as important causes of neonatal deaths and contributes to $60 \%$ to $80 \%$ of all neonatal deaths.
\end{abstract}

\section{Objectives :}

to assess the frequency of deaths in low birth weight neonates and it's relation to selected neonatal, labour and maternal characteristics.

\section{$\underline{\text { Patients and Methods : }}$}

A prospective study was carried out on low birth weight newborns admitted to neonatal care units in Basrah Maternity and Children Hospital for four months( from 1st of February till the end of the May 2008) on 508 newborns with low birth weight out of 1338 neonates admitted during the study period. One hundered-ninty one (191) neonates with low birth weight died, their death was studied in relation to neonatal, labour, delivery and maternal characteristics from data collection by special questionnaire.

\section{$\underline{\text { Results : }}$}

It was found that $(68.95 \%)$ of total deaths had low birth weight, male to female ratio was (1.4:1). The death was significantly related to gestational age, weight, growth status (being small for gestational age) and male sex. ( $\mathrm{P}$ value was $<0.001$ ). The most common causes of deaths were respiratory distress syndrome $(54.97 \%)$ followed by sepsis (19.37\%. Other neonatal characteristics like postnatal referral, early death, and hospitalization period of less than seven days, need for resuscitation at time of birth and multiple pregnancies were associated with increased risk of death. ( $P$ value $<0.001)$.Hospital delivery, non-complicated delivery and normal vaginal deliveries were 


\section{Thi-Qar Medical Journal (TQMJ): Vol.(14), No.(2), 2017 \\ Email:utjmed@utq.edu.iq \\ Web Site: https://imed.utq.edu.iq}

associated with decreasing neonatal mortalities.(P value <.001). Young age mothers (less than twenty years), Primgravidae, those who had anemia in pregnancy or had poor antenatal care were more liable to have neonatal death, while mortality rate was significantly lower among breastfed neonates compared to formula fed babies.

\section{Conclusions :}

The frequency of low birth weight and their deaths were high, the death was related to weight, gestational age, growth status, early neonatal period, complicated labour, caesarean section, young primi mother and maternal anemia. Prevention of prematurity and intrauterine growth retardation causes by good antenatal care, skilled attendance at births, and availability of surfactant therapy can reduce mortality.

Key words: Low birth weight Prematurity small for gestational age neonatal deaths Basrah

\section{Introduction:}

$1.42 \%$ of all births. Approximately $3,952,841$ US births were reported in

It is estimated that $15 \%$ to $20 \%$ of all births worldwide are LBW ; body weight $<2500 \mathrm{~g}$ ) representing more than 20 million births a year. low birth weight is a global concern The consequences of low birth weight include fetal and neonatal mortality and morbidity, poor cognitive development and an increased risk of chronic diseases later in life such as diabetes and cardiovascular disease. There are multiple causes of low birth weight, including prematurity, intrauterine growth retardation, early induction of labour or caesarean birth ,multiple pregnancies, infections and chronic conditions such as diabetes and high blood pressure . ${ }^{(1)}$ Low birth weight (LBW) was noted in $7.99 \%$ of united state births. Very low birth weight (VLBW) (less than $1500 \mathrm{~g}$ ) was noted in

2012. An extremely low birth weight (ELBW) infant is one with a birth weight of less than $1000 \mathrm{~g}$. Most extremely low birth weight infants are also the youngest of premature newborns, usually born at 27 weeks' gestational age or younger. ${ }^{(2)}$ The vast majority of newborn deaths take place in developing countries where access to health care is low. (3) Neonatal mortalities continue to occur at high levels in Iraq (23 per 1,000) live births, higher than developed countries with higher levels of antenatal care. United Kingdom had a neonatal mortality of 4 per 1000 in 2010, in Iran neonatal mortality rate is 12.5 per $1000 .^{(4)}$ Of the 2.44 million global deaths resulting from perinatal causes, $97 \%$ occur in 
developing countries. So LBW and perinatal mortality are public health problems of great importance in these countries. According to the World Bank/World Health Organization (WHO) study of the global burden of disease, low birth weight (LBW) and other perinatal causes are a leading cause of death and disability. It is widely recognized that weight at birth is an important indicator of fetal and neonatal health, and is strongly associated with fetal, neonatal, and post neonatal mortality. In 2014, preterm birth affected about 1 of every 10 infants born in the United States. Preterm birth is the greatest contributor to infant death, with most preterm-related deaths occurring among babies who were born very preterm (before 32 weeks. ${ }^{(5)}$ Rates of survival to discharge increased with increasing gestational age. Infants at the lowest gestational ages were at greatest risk for morbidities ${ }^{(6)}$. Survival correlates with gestational age for infants who are appropriate for gestational age (AGA). In 2010, infant mortality rates were 24 times higher for infants with low birth weight $(<2500 \mathrm{~g})$ and 100 times higher for those with very low birth weight $(\mathrm{VLBW})(<1500 \mathrm{~g})$ than for infants with birth weights of $2500 \mathrm{~g}$ or more. Female sex and single birth have a more favorable outcome ${ }^{(2)}$ It was observed that the lower the level of education and income of pregnant women, the higher the "low birth weight" and "perinatal mortality" outcomes. ${ }^{(7)}$ Maternal anemia is commonly considered a risk factor for low birth weight (LBW) babies some studies have demonstrated a strong association between low hemoglobin before delivery and LBW babies ${ }^{(8)}$ while mean birth weight of babies born to anemic mothers was marginally lower compared to that of babies born to no anemic mothers in another study.${ }^{(9)}$ This study was done in Basrah Maternity and Children Hospital (neonatal units) on LBW to assess the frequency and death in relation to some neonatal, labour and maternal characteristics.

\section{Patients and Methods :}

Patients: This prospective study was carried out at Basrah Maternity and Children Hospital in neonatal care units, the first neonatal unit (inborn deliveries) and second neonatal unit (out born deliveries where cases from other hospitals other than Maternity and Children Hospital ,home deliveries , referred cases from private clinics or peripheries of Basrah were admitted ) Data from 508 admitted neonates with LBW $(<2500 \mathrm{~g})$ were analyzed during the time of the study (from the first of February to the end of May 2008).

The total number of neonates admitted to both neonatal care unites was 1338 , out of them 508 neonates were with LBW ( $<2500 \mathrm{~g})$. Out of total 508 neonates 191 neonates with LBW died during their admission to the neonatal wards ; 113 were male and 78 female

Data collection: Neonatal information included age, weight, sex, being referred or not, gestational age (by history of last menstrual period LMP or ultrasound), cause of admission, , date of 
admission, date of discharge and , duration of admission, need for resuscitation at delivery (including intubation) or not, need immediate admission or not, and being the product of single or multiple gestation and cause of death,refered from other hospital or private clinic or not referred ( inborn deliveries). Obstetric information regarding place of delivery, type of delivery (normal vaginal, assisted delivery or caesarian section) and delivery complication including (antepartum hemorrhage ((APH)), malpresentation, premature rupture of membranes ((PROM)), obstructed labor, rupture uterus).Maternal information's including maternal age, weight, last hemoglobin (as mentioned by the mother from last ANC visit or from the labour room record) Anemia was classified as no anemia if $\mathrm{Hb}$ was more than $10 \mathrm{~g} / \mathrm{dl}$. (10) Other studied variables were parity, maternal medical diseases and pregnancy complications(like maternal diabetes, pregnancy induced hypertension, severe uterine contractions and early pregnancy vaginal bleeding), history of urinary tract infection UTI, and antibiotic treatment during labor ,ANC attendance(regular((one/month)), irregula $\mathrm{r}((<\mathrm{one} / \mathrm{month}))$ or no ANC $)$, history of previous delivery of LBW neonate or abortion ,maternal education and employment, residence, breast feeding of the current baby and evidence of consanguineous marriage. Maternal consent was taken for data collection.

Assessment and follow up of patients:

The admitted neonates were assessed regarding signs of IUGR (long, thin appearance with peeling, parchment-like dry skin, alert expression, meconium staining of the skin, and long nails, loss of subcutaneous fat)and their gestational age were assessed in addition to the history by the New Ballard Score.$^{(11)}$ These neonates were followed by examination for any congenital anomaly, weight for all was recorded by weight scale with light clothes then assessments of the growth status with the assistance of the Fenton`s intrauterine growth chart was done. All the (508) neonates were followed until discharge or death, (191) of them died, Neonatal deaths were studied in relation to some neonatal and maternal characteristics.Statistical analysis for neonatal, labuor and maternal characteristics to asses the risk factors effecting death was done using SPSS program, data were expressed and comparisons of proportions was performed using chi square, P-value of < 0.05 was considered as statistically significant, P-value of $<0.01$ as highly significant and $\mathrm{P}$-value of $<0.001$ as extremely significant.

\section{Results :}

It was observed that (38\%) of the admission to the neonatal units had LBW and $68.95 \%$ of the total death had LBW. Among LBW infants (37.59\%) died Table-1., with significant statistical difference in the frequency of deaths over the 4 months study period figure-1. It was found that $91.6 \% \%$ of deaths were preterm, $8.4 \%$ were fullterm. 175 from $396(44 \%)$ of preterm died while 16 from $106(15 \%)$ of full term died the difference 


\section{Thi-Qar Medical Journal (TQMJ): Vol.(14), No.(2), 2017 \\ Email:utjmed@utq.edu.iq \\ Web Site: https://imed.utq.edu.iq}

was statistically significant .More death was significantly higher among male neonates with LBW $(41.80 \%)$ than females $(32.70 \%)$ with a male: female ratio of $(1.4: 1), \quad$ (P value $<0.001$ ) table $2 \mathrm{~A}$. The death was significantly related to birth weight ( $\mathrm{p}$ value $<$ 0.001) Table 2B. It was also found that that premature infants who were small for gestational age had mortality rate of $(46.11 \%)$ followed by premature who were appropriate for gestational age $(41.4 \%)$, the least mortality rate was among full term SGA. So death was significantly related to growth status, $(\mathrm{P}$ value <.001), figure-2.It was found that the commonest cause of death among LBW was respiratory distress syndrome $(54.97 \%)$, followed by sepsis (19.37\%), congenital malformation which include(congenital heart disease, CNS and neural tube defect, gastrointestinal anomalies and Down syndrome) (7.85\%), pneumonia (4.7\%), Kernicterus in (3.66\%), birth asphyxia $(2.08 \%)$ and other causes( sever IUGR , hypoglycemia , extreme prematurity, neonatal convulsion, necrotizing enterocolitis ) constitute for (5.75\%) of all deaths figure- 3 . Table 4-A demonstrates that most deaths were non-referred cases $(84.82 \%)$ in comparison to referred cases $(15.18 \%)$. Most deaths $(83.76 \%)$ had hospitalization less than 7 days versus $(16.24 \%)$ of cases with hospitalization of more than 7 days. Also it was observed that $(63.87 \%)$ of deaths were ( $<7$ days) of age and $(36.13 \%)$ had age $>7$ days. Aggressive resuscitation including endotracheal intubation was present in $(5.75 \%)$ of dead while $(94.25 \%)$ didn't need resuscitation. Single tone pregnancy was present in $(81.67 \%)$ of deaths and multiple pregnancies in (18.33\%).The results are statistically significant.Table 4-B had demonstrated that mortality was more among home delivered infants, $(61,32 \%)$ in comparison of $(31.34 \%)$ of hospital delivered cases, it was observed also that deaths had occurred more among assisted vaginal delivery and caesarean section $959.74 \%$ ) than normal vaginal delivery(33.64\%). S value was $<0.001$.Table 5 had demonstrated that neonatal death were more among young mothers $(<20$ years of age), (the results were statistically significant with an odd ratio of (5.3). Also first born babies were more liable to die than subsequent births (the results were statistically significant with an odd ratio (3.3). Maternal anemia during pregnancy was associated significantly with neonatal death with an odd ratio of (4.7). Mothers who were not attending ANC had more neonatal death, (the results were statistically significant with an odd ratio of (1.1). Breast feeding was associated with less death (the results were statistically significant with an odd ratio of (12.1).

\section{Results :}

Table1 A-frequency of LBW

\begin{tabular}{|l|l|l|l|}
\hline Birth weight & Alive & Dead & Total \\
\hline Normal & 744 & 86 & 830 \\
\hline LBW & 317 & 191 & 508 \\
\hline Total & 1061 & 277 & 1338 \\
\hline
\end{tabular}


Thi-Qar Medical Journal (TQMJ): Vol.(14), No.(2), 2017

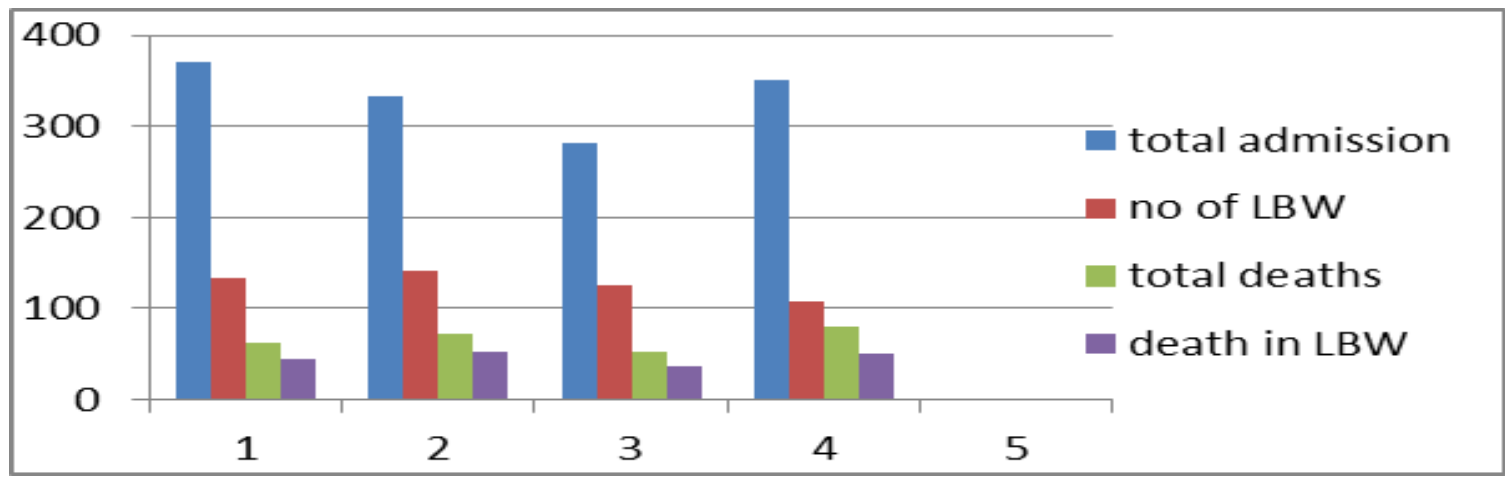

Figure-1 Frequency of LBW and their deaths in different months (Feb.,March., April, May)

Figure-2 death in relation to type of LBW

Table-2 Neonatal Death in Relation to Gestational Age, Sex, Body Weight and Type of LBW

Table-2(A) Death in Relation to Gestational Age and Sex

\begin{tabular}{|c|c|c|c|c|c|c|}
\hline \multirow{2}{*}{$\begin{array}{l}\text { Gestational } \\
\text { Age(weeks) }\end{array}$} & \multirow{2}{*}{$\begin{array}{l}\text { No.of } \\
\text { death/total } \\
\text { No. of age } \\
\text { category }\end{array}$} & \multirow[t]{2}{*}{$\%$} & \multicolumn{2}{|c|}{ Male neonates } & \multicolumn{2}{|c|}{ Female neonates } \\
\hline & & & No. & $\%$ & No. & $\%$ \\
\hline$<28$ & $10 / 10$ & 100 & 6 & 5.30 & 4 & 5.12 \\
\hline 28-32 & $58 / 114$ & 50.81 & 34 & 30.09 & 24 & 30.76 \\
\hline $32-36$ & $107 / 272$ & 39.32 & 61 & 53.98 & 46 & 58.97 \\
\hline $\begin{array}{l}\text { Total } \\
\text { preterm }\end{array}$ & $175 / 396$ & $44.19 *$ & & & & \\
\hline $\begin{array}{l}\geq 37(\text { full } \\
\text { term) }\end{array}$ & $16 / 106$ & $15.07 *$ & 9 & 7.96 & 7 & 7.30 \\
\hline
\end{tabular}


Thi-Qar Medical Journal (TQMJ): Vol.(14), No.(2), 2017

Email:utjmed@utq.edu.iq

Web Site: https://imed.utq.edu.iq

\begin{tabular}{|l|l|l|l|l|l|l|}
\hline Total & 191 & $113 / 270$ & $41.80^{* *}$ & $78 / 238$ & $32.70 * *$ \\
\hline
\end{tabular}

$* \mathrm{P}$ Value $<0.005 * * \mathrm{P}$ Value $<0.001$

Table-2 (B) Neonatal Deaths in Relation to Body Weight and Type of LBW

\begin{tabular}{|c|c|c|c|c|}
\hline $\begin{array}{c}\text { Body weight(gm) } \\
\text { No. }\end{array}$ & LBW death (NO.) & $\%$ & $\begin{array}{c}\text { Mean } \\
\text { Wt.(gm) }\end{array}$ & P-value \\
\hline $500-749-9$ & 9 & 100 & 641 & \\
\hline $750-999-20$ & 18 & 90 & 830 & \\
\hline $1000-1249-63$ & 51 & 80.95 & 1119 & \\
\hline 1250-1499-32 & 25 & 78.12 & 1312 & \\
\hline 1500-1749-30 & 22 & 73.30 & 1555 & \\
\hline 1750-1999-100 & 23 & 23 & 1829 & \\
\hline $2000-2249-148$ & 27 & 18.24 & 2066 & \\
\hline 2250-2500-106 & 16 & 15.09 & 2394 & \\
\hline $2250-2500$ & $16 / 106$ & 15.09 & 2394 & \\
\hline
\end{tabular}

Figure- (3) The Causes of Death Among LBW Neonate 
Thi-Qar Medical Journal (TQMJ): Vol.(14), No.(2), 2017

Email:utjmed@utq.edu.iq

Web Site: https://imed.utq.edu.iq

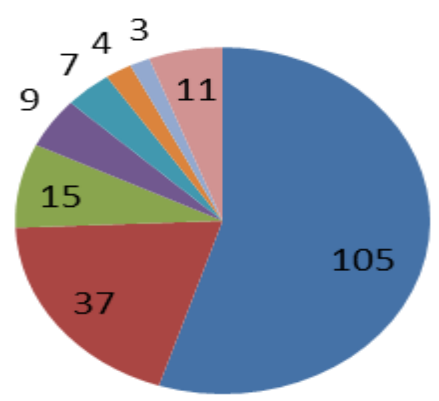

- Hyaline membrane disease $\square$ Sepsis

- Congenital malformation pneumonia

Kernicterus

Birth asphyxia

Meconium aspiration $\quad$ others

Table - 4 Neonatal Deaths in Relation to Selected Neonatal, labour and Delivery Characteristic

Table -4 A Deaths in Relation to Selected Neonatal Characteristics

\begin{tabular}{|c|c|c|c|}
\hline Patient referral & No. & $\%$ & p-value \\
\hline Yes & 29 & 15.18 & $<.001$ \\
\hline No & 162 & 84.82 & \\
\hline $\mathbf{1 - 7}$ & & & \\
\hline duration of hospitalization(days) & 160 & 83.76 & $<0.001$ \\
\hline Time of death & 31 & 16.24 & \\
\hline early death & 122 & 63.87 & $<0.05$ \\
\hline late death & 69 & 36.13 & \\
\hline need for resuscitation & & & \\
\hline Yes & 11 & 5.75 & $<0.001$ \\
\hline No & 180 & 94.25 & \\
\hline Single & & & \\
\hline
\end{tabular}


Thi-Qar Medical Journal (TQMJ): Vol.(14), No.(2), 2017

Table -4B Neonatal Death in Relation to Certain labour and Delivery Characteristics

\begin{tabular}{|c|c|c|c|}
\hline Place of delivery & No. & $\%$ & p-value \\
\hline Hospital with or without NCU & $126 / 402$ & 31.34 & $<0.001$ \\
\hline Home delivery & $65 / 106$ & 61.32 & \\
\hline total & $191 / 508$ & & \\
\hline Evidence of complication & & & \\
\hline Complicated labour & $89 / 128$ & 69.53 & $>0.05$ \\
\hline Non Complicated labour & $102 / 380$ & 26.84 & \\
\hline Total & 191 & & \\
\hline Type of delivery & & & \\
\hline NVD & $145 / 431$ & 33.64 & $<0.001$ \\
\hline $\begin{array}{c}\text { Assisted vaginal delivery\&ceaserian } \\
\text { section }\end{array}$ & $46 / 77$ & 59.74 & \\
\hline Total & 191 & & \\
\hline
\end{tabular}


Thi-Qar Medical Journal (TQMJ): Vol.(14), No.(2), 2017

Email:utjmed@utq.edu.iq

Web Site: https://imed.utq.edu.iq

Table -5 Neonatal Death in Relation to Some Maternal Characteristics

\begin{tabular}{|c|c|c|c|c|}
\hline \multirow{2}{*}{$\begin{array}{l}\text { Maternal characteristic } \\
\text { Maternal age(years) }\end{array}$} & \multicolumn{4}{|c|}{ Logistic Regression } \\
\hline & $\begin{array}{l}\text { Regression } \\
\text { coefficient }\end{array}$ & S.E & $\mathrm{p}$-value & Odd ratio(0R) \\
\hline$<20$ & \multirow[t]{3}{*}{1.677} & \multirow[t]{3}{*}{0.639} & \multirow[t]{3}{*}{0.009} & \multirow[t]{3}{*}{5.348} \\
\hline 20-35 & & & & \\
\hline$>35$ & & & & \\
\hline \multicolumn{5}{|l|}{ Parity } \\
\hline Primigravida & \multirow[t]{3}{*}{1.223} & \multirow[t]{3}{*}{0.639} & \multirow[t]{3}{*}{0.056} & \multirow[t]{3}{*}{3.399} \\
\hline $1-5$ & & & & \\
\hline$>5$ & & & & \\
\hline Evidence of anemia & 1.314 & 0.143 & 0.028 & 4.731 \\
\hline Maternal weight $<45 \mathrm{KG}$ & 0.022 & 0.024 & 0.345 & 1.023 \\
\hline UTI during pregnancy & -.247 & 0.681 & 0.717 & .781 \\
\hline Antibiotic therapy & 0.041 & 0.673 & 0.951 & 1.042 \\
\hline Glucocorticoid & 0.043 & 0.543 & 0.937 & 1.044 \\
\hline ANC attendance & & & & \\
\hline Regular & 1.702 & 0.750 & 0.023 & 1.182 \\
\hline
\end{tabular}




\begin{tabular}{|c|c|c|c|c|}
\hline Irregular & & & & \\
\hline No ANC & & & & \\
\hline Maternal education & & & & \\
\hline Illiterate & -0.581 & 0.368 & 0.114 & 0.559 \\
\hline Primary education & & & & \\
\hline Secondary education & & & & \\
\hline higher education & & & & \\
\hline Residence & & & & \\
\hline Rural & -0.015 & 0.041 & 0.721 & 0.986 \\
\hline Urban & & & & \\
\hline history of previous LBW & -0.047 & 0.630 & 940 & 0.954 \\
\hline Chronic medical illness & -0.239 & 0.663 & 0.719 & 0.788 \\
\hline Breast feeding & 2.494 & 0.823 & 0.002 & 12.104 \\
\hline Consanguineous marriage & 0.116 & 0.389 & 0.764 & 1.124 \\
\hline
\end{tabular}

\section{Discussion :}

The percentage of death in hospitalized LBW was evaluating the overall progress of perinatal care in a community ${ }^{(11)}$. A total of $191(37.59 \%)$ have been died from the LBW category (508) this is lower to what found in Middle East region like in Iran it was $(54.6 \%)^{(12)}$,in Egypt $(61.9 \%)^{(13)}$, in India $(69 \%)^{(14)}$ in Saudi Arabia was $(71 \%)^{(11)}$ and in Yemen $(80.6 \%)^{(15)}$. The death was related significantly to gestational age, this was observed in developing and developed countries ${ }^{(16)}$, in relation to groups of gestational age it was observed that all those the $<28$ weeks of gestation died while (33\%) of LBW in Japan have died as reported by Osahaki et al ${ }^{(17)}$.It was observed that $(54.83 \%)$ of LBW $<32$ weeks of gestation died,this result is higher than what was observed in other studies in
Iran ${ }^{(12)}$ and Nepal $(42 \%, 46.9 \%)$. (18) Respectively, this may be related to difference in the management of this group. Male LBW babies were more vulnerable to death than females this in agreement with different studies in Middle East in regarding male sex as a risk factor of death ${ }^{(12,19)}$. The male to female ratio was $(1.4: 1)$ was higher than was found in Iran (1.2:1) ${ }^{(12)}$, and Egypt $(1.1: 1)^{(13)}$, and in general developing countries population (1.3:1) ${ }^{(20)}$, but lesser than in Japan $(2: 1)^{(17) . ~ T h i s ~ m a y ~}$ be due to difference in population. In the current study all the neonates with a birth weight $<750$ grams died, compared to $(15 \%)$ with a birth weight between 2250-2500 grams, this was similar to other studies in Japan ${ }^{(21)}$, South Africa (22). Regarding causes of death it was observed that RDS was observed in $(54.93 \%)$ of cases where most of them were preterm for them facilities of 
assisted ventilation were lacking, in $\mathrm{Japan}^{(17)}$ it was observed that (13.9\%) of death had RDS this lower frequency of cases of RDS was due to availability of more facilities of management on both levels prenatally and after delivery .Complicated labour was observed to be associated with more deaths than noncomplicated labour, this is comparable to a case control study in New Guinea which have shown that complicated labour was associated with more neonatal deaths $(59.4 \%)$ than noncomplicated labour ${ }^{(23)}$, this was explained by that complications during labour and delivery are associated with neonatal problems like RDS , asphyxia, early sepsis, hypoglycemia, which may lead to more chance of mortality . Vaginal delivery was associated with less mortality than assisted vaginal or caesarean section, this was similar to other study in Nepal which found that caesarean section deliveries were more associated with early neonatal mortality $(50 \%)$, than normal vaginal deliveries $(20 \%)^{(18)}$. This can be explained by possibility of occurrence of some complications more with caesarean section like infection, RDS, effect of anesthesia which may lead to increasing mortality. More neonatal deaths related to young mothers $(<20$ years) ,this was similar to New Guinea (24) which demonstrated perinatal mortality of $(13.8 \%)$ to young mothers ,this is explained by occurrence of more LBW (SGA and prematurity) among young mothers ${ }^{(16)}$.Maternal anemia during pregnancy was found to be associated significantly with neonatal death. As in other study in New Guinea. ${ }^{(24)}$, this is explained by occurrence of IUGR more with maternal anemia leading to increase death.ANC attendance was found to be associated with less deaths, this was similar to many studies in Egypt ${ }^{(13)}$, New Guinea (24), and India (14) and explained by reduction in adverse neonatal outcome with good ANC. Breast feeding was found to decrease significantly neonatal mortality due to its well-known nutritional and immunological functions that lead to decrease death. (25) Regarding other maternal characteristics maternal UTI was associated with early sepsis and increased mortality ${ }^{(16)}$ but that was not found in this study. Intrapartum receiving of antibiotics for mother with prolonged rupture of membrane decrease early sepsis and its mortality ${ }^{(26)}$ but was not found in this study. Steroid therapy for premature contractions is effective in decreasing incidence of prematurity and death ${ }^{(27)}$ but was not associated with decreasing deaths in this study. Maternal weight was found to be more associated with delivery of LBW newborn, In mothers with low weight $(<45 \mathrm{~kg})$, low birth weight babies were three times more common than in mothers with normal weight ${ }^{(28)}$,its relation to death was not proved in this study. low education is one of factors that contribute to high risk pregnancy ${ }^{(16)}$ Educated mothers know how to deal with their LBW babies and know when to sake advice so less mortality occurred with more educated mothers but this study had shown no significant association between maternal education and deaths Mothers from rural areas were far from medical consultation and early management of neonatal problems so will have more neonatal deaths ${ }^{(13)}$ this was not demonstrated in this study. It was shown that history of previous 
Web Site: https://imed.utq.edu.iq

LBW was associated with subsequent LBW and increase death ${ }^{(1)}$ but this was not shown in this study. Consanguineous marriage was not observed to be associated with increasing death although it was known that it was associated with more neonatal problems and deaths ${ }^{(29)}$. Medical problems were associated with decrease in placental circulation leading to more LBW and then deaths ${ }^{(17)}$ but this was not documented in this study.So (37.90\%) of admitted neonates had LBW, $(37.5 \%)$ of them died and constitutes $(68.95 \%)$ of total neonatal death. The death was related to weight, gestational age, growth status, early neonatal period, complicated labour, caesarean section ,young mother, bad ANC ,maternal anemia. Breast feeding decrease deaths. Prevention of prematurity and IUGR causes by good ANC, health education and home visits to pregnant mothers and neonates in $1^{\text {st }}$ week, skilled attendance at births, availability of surfactant therapy , continuous positive airway pressure and mechanical ventilation and immediate exclusive breast feeding can reduce mortality. It is suggested to repeat the study recently for better comparision.

\section{References}

1- WHO publication /2014 .WHA Global Nutrition Targets 2025: Low Birth Weight Policy Brief

2- WHO publication. WHO Media center. Care of the preterm and/or lowbirth-weight newborn.Factsheet.January 2016. E-mail: mediainquiries@who.int

3- WHO publication. WHO Media center. Newborns: reducing mortality.
Fact sheet January 2016. E-mail: mediainquiries@who.int

4-Nazar P Shabila, Hamdia M Ahmed, Maryam Y Yasin. Women's views and experiences of antenatal care in Iraq: a $Q$ methodology study. BMC Pregnancy and Childbirth 2014; 14:43

5- Michael S. Kramer and Cesar G.victora. Low Birth Weight and Mortality. In Richard D. Semba MD, MPH, Martin W. Bloem MD, PhD, Peter Piot MD, PhD Nutrition and Health in Developing countries.. Human Press Inc., Totawa,NJ Nutrition and Health Series .2008

6-Stoll BJ, Hansen NI, Bell EF, Shankaran S, Laptook AR. Neonatal outcomes of extremely preterm infants from the NICHD Neonatal Research Network. Pediatrics . 2010 Sep; 126(3)

7- Rosa Maria Soares Madeira Domingue' Maria do Carmo Le' Zulmira Maria de Araújo Hartz' Marcos Augusto Bastos Dias' Marcelo Vianna Vettore Access to and utilization of prenatal care services in the Unified Health System of the city of Rio de Janeiro, Brazil. Rev. Bras. epidemiol. 2013 Dec; 16(4).

8-Ahmad MO, Kalsoom U, Sughra U, Hadi U, Imran M.-J. Effect of maternal anemia on birth weight. Ayub Med Coll Abbottabad. 2011 Jan-Mar; 23(1):77-99

9-K Jagadish Kumar, N Asha, D Srinivasa Murthy, MS Sujatha, and VG Manjunath. Maternal Anemia in Various Trimesters and its Effect on Newborn 
Weight and Maturity: An Observational Study. Ayesha. Int J Prev Med. 2013 Feb; 4(2): 193-199

10- Steer PJ hemoglobin concentration and birth weight Maternal.Am J Clin Nutr. 2000 May;71(5 Suppl):1285S-7S. 11- Bassuni W, Abbag F, Asindi A, Al Barki A, Al Binali A M. Neonatal deaths in the Asir region of Saudi Arabia experience in a referral neonatal intensive care unit .Annals of Saudi Medicine 1997;17( 5) :12-14.

12- keshtkaran A, Keshtkaran V. Factors Affecting Neonatal Death in Fars Province, Southern Iran, 2004. Middle East Journal of Family Medicine 2007; 5 (1):12-14.

13- Hong R., Beltran M. Low birth weight as a risk factor for infant mortality in Egypt. Eastern Mediterranean Health Journal 2008; 14(5):22-23.

14- Parmar V R, Grover N, Randhawa I, Bahl L. , Kaushal RK ,et al. Perinatal Mortality In Shimla. Indian Pediatrics 1994; 31:834-836.

15- Banajeh S M, Al-Rabee A M, AlArashi IH. Burden of perinatal conditions in Yemen: a 12-year hospitalbased study. Eastern Mediterranean Health Journal. 2005. May; 11 (4): 2223.

16- Stoll BT. The High risk pregnancy In: Robert M. Kliegman, MD, Bonita M.D. Stanton, MD, Joseph St. Geme, $\mathrm{MD}$ and Nina $\mathrm{F}$ Schor, $\mathrm{MD}, \mathrm{PhD}$. Nelson`s textbook of pediatrics. 20th edition, Philadelphia. WB Saunders Co, Elsevier 2015; 684-708
17- Osahaki R, Nakamora K. Factors Effecting Short Term Mortality in Japan. Tohoko J.Exp.Med. 2005; 20(5): 141.

18-Shrestha M, Manandhar DS, Dhakal S. Two year audit of perinatal mortality at Kathmandu Medical College Teaching Hospital. Kathmandu University Medical Journal 2006; 4(2) :176-181.

19-Quaderi S, Higiazi S. Causes of Infant Death in Jordan. Amman (JO): Higher Council of Science and Technology Final Report: 2003; 5: 3-4.

20-World Health Organization. Reducing Perinatal and Neonatal Mortality. Child Health Research Project Special Report 1999 Oct; 3-9.

21- Gagliardi L, Cavazza A, Brunelli A, Battaglioli M. Assessing mortality risk in very low birthweight infants: a comparison of CRIB, CRIB-II, and SNAPPE-II. Arch. Dis. Child. Fetal Neonatal Ed. 2004; 89: 419-422.

22- Donald D M, Steven L, Brianm C, Casey B, Kenneth J ,et al. Birth Weight In Relation To morbidity and Mortality Among Newborn Infants. The New England Journal of Medicine. 1999 April; 340 (16):1- 2.

23-Grandi C., Tapia J, Marshall G. An assessment of the severity, proportionality and risk of mortality of very low birth weight infants with fetal growth restriction a multicenter South American analysis. Journal of Pediatric 2005; 81(3):198-201.

24- Apeawusu B A, Cecil A K. A CaseControl Study Of Early Neonatal Deaths At The Port Moresby General Hospital 


\section{Email:utjmed@utq.edu.iq}

To Determine Associated Risk Factors. Png Med J 2002; 45(3-4):185-196.

25- McIntosh N, Stenson B. Newborn .In: McIntosh Helms P, Smyth R (eds).Forfar and Arneil's textbook of pediatrics 6thed .Philadelphia. Churchill Livingstone Co 2003:178-179.

26-Thilo E H, Rosenberg A A. Evaluation of the newborn infant. In: William W. Hay Jr, et al By McGrawHill Education. Current Pediatric Diagnosis \& Treatment 16th Ed: Europe 2002:14-25.
Web Site: https://imed.utq.edu.iq

27- Alma M, Rebecca S. Abnormalities of Fetal Growth. In: Taeusch, Ballard, Gleason (eds). Avery's Diseases of the Newborn. 8th edition, Elesvier Saunders .2004: 32-39.

28-Ojha N, Malla D S. Low Birth Weight at Term Relationship with Maternal Anthropometry. J Nepal Med Assoc 2007; 46: 52-56.

29- Mokhtar M M, Abdel-Fattah M M. Consanguinity and Advanced Maternal Age as Risk Factors for Reproductive Losses in Alexandria, Egypt. European Journal of Epidemiology 2001; 17: 559565 .

\section{دراسة حول وفيات الاطفال ناقصي الوزن في ردهات الخدج في مستثفى البصرة

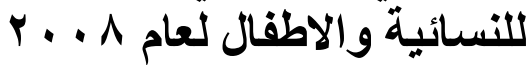

د. دائدة عبد الكريم منثر
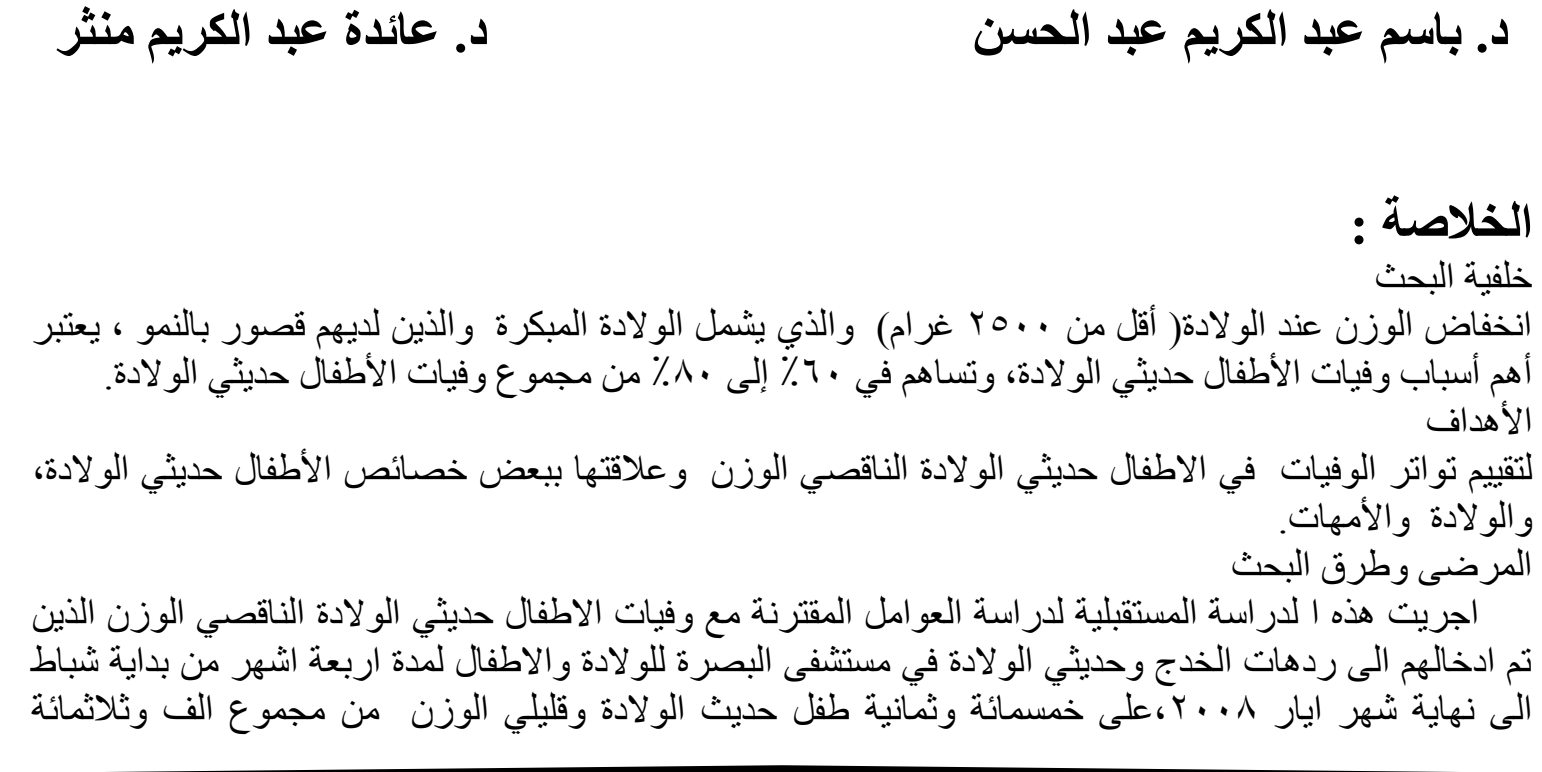
وثمانية وثلاثون (العدد الكلي للدخول)همائة وو احد وتسعون منهم قد توفو ا وقد تمت در اسة وفاتهم من حيث خصائص

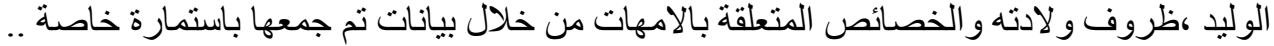

النتائج

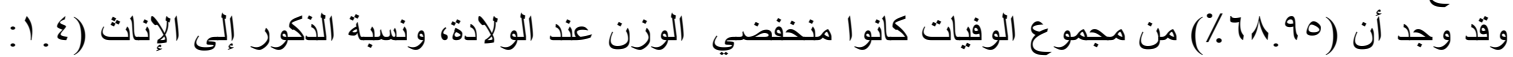

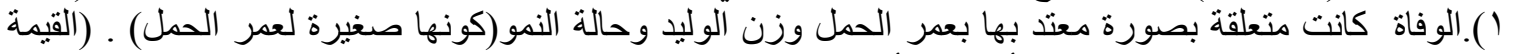

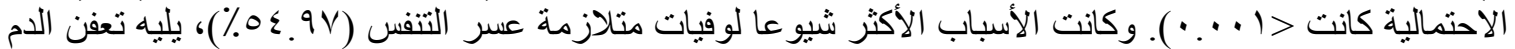

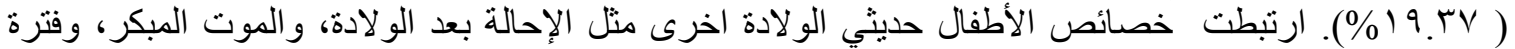

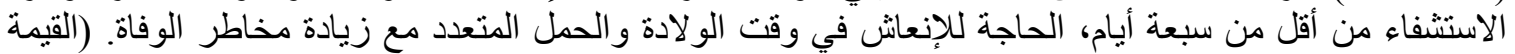

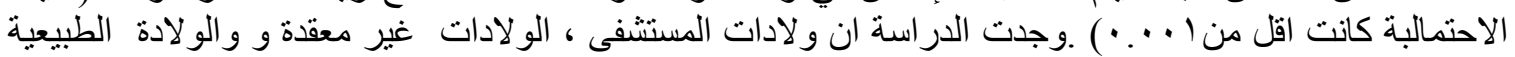

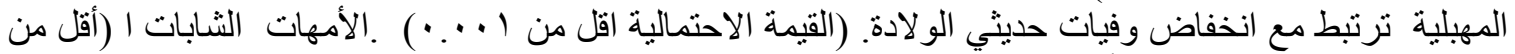

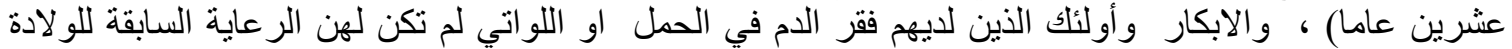

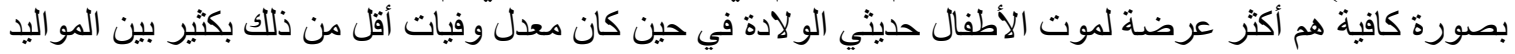

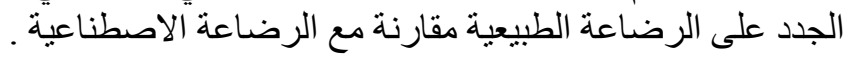

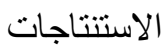

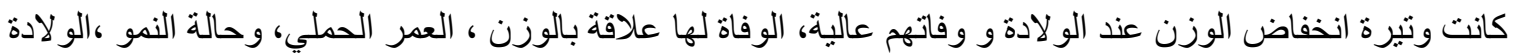

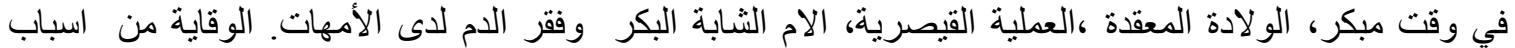

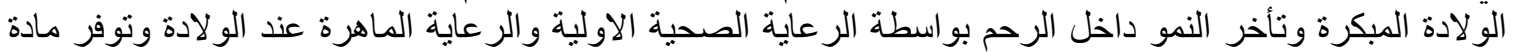

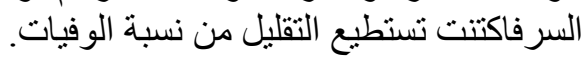
الكلمات المفتاحية ألفين

انخفاض الوزن عند الولادة ولادة مبكرة قصو النمو بالنسبة لعمر الحمل وفيات الحديثي الولادة البصرة 